\title{
The Development of Business-to-Business Magazines in China
}

\author{
Bohai Zhang
}

Published online: 23 April 2008

(C) The Author(s) 2008

\begin{abstract}
Business-to-Business (B2B) publications actually have a long history in China, beginning in the early twentieth century. After 1949, the Chinese economy became planned and regulated by the government, the former B2B magazines became their purpose to explain the government's industrial policies, chart business direction and exchange developmental experience. As China began its reform and opened to a market economy in the 1980s, traditional published B2B magazines began to reappear. Today almost 3,000 B2B magazines provide information about specific industries and services.
\end{abstract}

Keywords Business-to-Business publications · B2B magazines ·

Agriculture - Digital information services · Economy · Market economy ·

Online publishing · Planned economy · Transportation · Zhengzhou ·

Zhongguo

Actually, Business-to-Business (B2B) publications have appeared in China since the beginning of twentieth century and were published for certain industries, such as those publications of guilds' publications, like Business Report (Shangwu Bao, 1903), Gazette of the Chamber of Commerce (Shanghui Gongbao, 1906), and others. Many publications were published later for their respective industries, like Bank Weekly (Yinhang Zhoukan, 1917), Bank Monthly (Yinhang Yuekan, 1921), Banking (Yinhang Jie, 1940), Silkworm Journal (Canye Daobao, 1939), Newsletter of Tea (Chaye Tongxun, 1943), Security Market (Zhengquan Shichang, 1946), Capital market (Ziben Shichang, 1948), Ten-day Reports on Cereals (Liangqing Xunbao, 1932), Fuels Report (Ranliao Huibao, 1939), Stibonium Semimonthly (Tiye

\footnotetext{
B. Zhang $(\bowtie)$

China Periodicals Association, Room 1004,13 Building, 1st District Fangguyuan, Fangzhuang,

Beijing, China

e-mail: liyan-cpa@vip.sohu.com
} 
Banyuekan, 1948), etc., and some summary market guide publications like Economy Information (Jingji Qingbao, 1941), Economy and Operations (Jingji and Jingying, 1944), Commerce and Industry Monthly (Gongshang Yuebao, 1946) and Circle of Commerce and Industry (Gongshang Tiandi, 1947). There were many B2B publications besides those listed here available at the first half of twentieth century in China with its special publishing structure and market dynamics at that time. This period can be regarded as the time for pioneers of B2B publications in China's magazine market and showed the robust development of China's capitalism market at that time [1].

Since the Peoples Republic of China was founded in 1949, the Chinese economy was regulated by the way of planned development, and the government controlled all the industries. Those former B2B magazines became business guide publications carrying the content of the respective industrial policies, industrial business trends and industrial exchanges of developmental experiences. The ministries and commissions under the State Council were usually organizers and publishers of these B2B publications. A brief sample list of magazines includes the following titles: China Electric Power (Zhongguo Dianye, 1950), China Forestry (Zhongguo Linye, 1950), China Water Conservancy (Zhongguo Shuili, 1950), China Light Industrial Economy (Zhongguo Qinggongye Jingji, 1950), Commerce and Industry Administration (Gongshang Xingzheng Guanli, 1952), China Commerce and Industry (Zhongguo Gongshang, 1952), Architecture (Jianzhu, 1954), Construction of Cities and Countrysides (Chengxiang Jianshe, 1955), China Country Finance (Zhongguo Nongcun Jinrong, 1955), Country Work Newsletter (Nongcun Gongzuo Tongxun, 1956), China Foreign Trade (Zhongguo Duiwai Maoyi, 1956) and Economy Research (Jingji Yanjiu, a synthesized guide publication, 1955). They were highly authorized with a large coverage of content for their specific audiences. These magazines were also publications that focused on the economy of different industry sectors. However, they were different from the present B2B magazines because of governmental guidelines and the macro-economic planning background [2].

Since China began its reform and opening of the industry sectors in 1978s, B2B magazines rose again with the development of the new market economy. In a historical review of that recent development, the first B2B publication that would be noticed is the Computer World born in 1980s. It is a publication registered as a form of newspaper with the entrance of a whole new set of B2B magazines' production experiences. It became the operation model provided to the Chinese publisher under the guidance of and the cooperation with IDG, the American partner company. It was an important entry to note the great market profile with related income created by Computer World. Especially the large revenues generated by the advertising sales by a B2B publication, foreshowed the future of B2B publications in China. Furthermore, B2B magazines were started in many market segments since 1980s in China, many of which were adapted to the need of the new market economy from the former industrial publications that were established during the dominance of the planning-economy [3].

A recent statistic shows that there are almost 3,000 B2B magazines included in the total of about 9,000 magazines in China. The total includes over 400 business 
and finance magazines (from the circles of finance, business and management, fiscal principles, statistics and accounting) and over 2,400 industry and commerce magazines (over 1,100 engineering and manufacturing titles), about 460 titles of medical, health and sanitation, about 400 titles in the area of agriculture, forestry, stock raising and fishery, about 200 titles of computing and network communications, and about 150 of traffics and transportation). Most of the above listed magazines provide industrial information and services like industrial consulting, which have become an active platform for industrial advertising and have developed the present lineup of B2B magazines in China [3].

During the last 10 years of the twentieth century in China, there are two noticeable developments in China's magazine industry. Namely, some quality lifestyle and fashion magazines have come out which are in step with western fashion, and many B2B magazines were launched in many market sectors and industries which follow the progress of western B2B magazines. The former consumer publications can be seen like Trends, Elle, Rayli and the later can be seen from many B2B magazines named like managers, entrepreneurs, etc. and many industrial/professional magazines for the IT, mechanical engineering, security, real estate, automobile, medicine and medical instruments. Both of those two kinds of magazines published in the western world have influenced the development of China's magazine industry within related market segments and with their fabulous achievements. It is interesting to note that the quality lifestyle and fashion magazines comparatively grow all the time and most of them have developed very well despite of the intense competition in the field. The always changing market of B2B magazines certainly has and continues to help development and growth for these specialized publications. Therefore, some of those magazines can maintain their further development and profitable growth over the short term future. But others have limited growth potential and can develop to a lesser degree. It is hard for them to maintain market share and thus it is much easier to go financially downward. We can establish several rules to be followed by China's B2B magazines based on an analysis of the last 10 years covering the rise and fall of these publications over the past years. A careful analysis has identified the following five key factors for consideration:

1. The vitality of B2B magazines depends on their industries' economic strength and development. An industry with great potential can provide abundant editorial content and related advertising for its publications despite whether the industry is small or large. The B2B magazines in a certain industry can rise when the industry rises, and vice versa. That is the main reason why so many B2B magazines grew while others experienced financial weakness or failure during the last 10 years.

2. It is necessary for the B2B magazine to carry its mission for the industry sector that it serves. The publication needs to serve as the industry's eyes to help the industry report on the dynamics of the market and related trends. The second goal is to serve as the industry's consultant and provide reliable decisionmaking information and reference sources consistently. The added value will be the editorial selection of the pertinent information and data after carefully 
reviewing all sources of such information. Mission three for the $\mathrm{B} 2 \mathrm{~B}$ magazine is to be the industry's forum to identify or to warn of the problems the industry is or may be facing, and to publish fair-minded objective opinions for the industry. It needs to be the voice of the majority of its industry.

3. It is better for B2B magazines to be located in the area within the developed economy, potential of economy development and/or with economic and financial focus. It should be prudent for B2B magazines to recognize such geographic advantages. B2B magazines in the Coastland of Southeast China and in big cities with developed economy in China. For example a well known B2B magazine in Chongqing city, just benefits from the municipality directly under the Central Government. There is a special position of the development of economy in Southwest China and its transportation with related communications extending in all directions. The well-known B2B magazine Sales and Market (Xiaoshou yu Shichang) in Zhengzhou just re-establishes to the long business history of Zhongyuan area (Central China) and benefits from the economic prosperity of Zhengzhou, the well-known business city.

4. B2B magazines need to establish a consolidated and credible long relationship with advertising for product manufacturers in relation to its industry, including the upper market products that the industry is depending on and brand products the industry is marketing. That is a powerful and necessary economical support for a B2B magazine to survive and to get revenues for further development. It is hard and even impossible for a B2B magazine to survive and grow without powerful advertising income.

5. It is better for the B2B magazine to show its publication identity and brand through excellent business operations with great reporting and editorial skills in order to provide reliable information services for the industry. There have been so many newborn B2B magazines in recent years, but most of them have not differentiated themselves from a cluster and made it difficult for readers to distinguish who is who. For example, there have been many new B2B magazines for entrepreneurs and financial managers. B2B magazine publishers need to establish the different and the special qualities of timely and relevant content besides their internal highly skilled business management and perfect publications technology. Only the B2B magazine showing its brand and its special editorial mission can get the chance to win in today's B2B magazine market with more and more intense competition.

Finally, we must notice that the traditional B2B magazines providing services for the industry with information and market data are facing the challenges of online publishing. China is now experiencing the rapid development from only in print and conferences to the new era of providing specialized information with easy search for and retrieval of just-in-time online services. Online B2B publications are getting more and more market share, and the traditional B2B magazine publishers have to think about the strategies in order to keep their present market position in the future. It has been a proven that there is a feasible way for the B2B magazine publishing industry to extend the traditional B2B magazines to the Internet and develop the necessary network platform in order to get the financial revenues from both printed 
hardcopy publications and online information services. It should be noted that the digital or online publications should be the prime source of income and profitability in the field. The opportunity for the traditional B2B magazine is to develop the strategy and then implementation of adding the special digital online information services is the path to survival. The B2B magazine needs to keep the advantages during the transition from only print to also online before the competition takes the market share away. It would be true that the traditional B2B magazines and their online services as a combination or completely new online B2B services will coincide with each other to provide for better information for the industries in China in the future.

Open Access This article is distributed under the terms of the Creative Commons Attribution Noncommercial License which permits any noncommercial use, distribution, and reproduction in any medium, provided the original author(s) and source are credited.

\section{References}

1. The Edit Group of Chinese Books Catalogue Union, editors. Chinese Magazine Consolidate Catalogue, Additional Edition. China Documentation Publishing House; 1981.

2. Zhang Bohai, editor. Catalogue of Chinese Magazines. Magazine Publishers Manual, vol. 2. Tianjin People's Publishing House; 1993.

3. Above data reference to Report of Classification of Chinese Magazines, by Chinese Institute of Publishing Science; 2006. 